\title{
Lunar Outpost Life Support Architecture Study Based on a High Mobility Exploration Scenario
}

As scenarios for lunar surface exploration and habitation continue to evolve within NASA's Constellation program, so must studies of optimal life support system architectures and technologies. This paper presents results of a life support architecture study based on a 2009 NASA scenario known as Scenario 12. Scenario 12 represents a consolidation of ideas from earlier NASA scenarios and includes an outpost near the Lunar South Pole comprised of three larger fixed surface elements and four attached pressurized rovers. The scenario places a high emphasis on surface mobility, with planning assuming that all four crewmembers spend roughly $50 \%$ of the time away from the outpost on 3-14 day excursions in two of the pressurized rovers. Some of the larger elements can also be mobilized for longer duration excursions. This emphasis on mobility poses a significant challenge for a regenerative life support system in terms of costeffective waste collection and resource recovery across multiple elements, including rovers with very constrained infrastructure resources.

The current study considers pressurized rovers as part of a distributed outpost life support architecture in both stand-alone and integrated configurations. A range of architectures are examined reflecting different levels of closure and distributed functionality. Different lander propellant scavenging options are also considered involving either initial conversion of residual oxygen and hydrogen propellants to water or initial direct oxygen scavenging. Monte Carlo simulations are used to assess the sensitivity of results to volatile high-impact mission variables, including the quantity of residual lander propellants available for scavenging, the fraction of crew time away from the outpost on excursions, total extravehicular activity hours, and habitat leakage. Architectures are evaluated by estimating surpluses or deficits of water and oxygen per 180-day mission and differences in fixed and 10-year-total equivalent system mass (ESM) relative to a reference case.

Results are presented based on current assumptions for Scenario 12 and based on Monte Carlo simulations with assumed probability distributions for the high-impact mission variables. The calculated probability of no water or oxygen resupply from Monte Carlo simulations provides a quantitative measure of system robustness that can be used for cost/benefit analyses to identify leading architecture candidates. Areas of technology improvement that are likely to have a significant impact are also suggested. 


\title{
Lunar Outpost Life Support Architecture Study Based on a High-Mobility Exploration Scenario
}

\author{
Kevin E. Lange ${ }^{1}$ \\ Jacobs Technology, Houston, TX, 77058 \\ and \\ Molly S. Anderson ${ }^{2}$ \\ NASA Johnson Space Center, Houston, TX, 77058
}

\begin{abstract}
This paper presents results of a life support architecture study based on a 2009 NASA lunar surface exploration scenario known as Scenario 12. The study focuses on the assemblycomplete outpost configuration and includes pressurized rovers as part of a distributed outpost architecture in both stand-alone and integrated configurations. A range of life support architectures are examined reflecting different levels of closure and distributed functionality. Monte Carlo simulations are used to assess the sensitivity of results to volatile high-impact mission variables, including the quantity of residual Lander oxygen and hydrogen propellants available for scavenging, the fraction of crew time away from the outpost on excursions, total extravehicular activity hours, and habitat leakage. Surpluses or deficits of water and oxygen are reported for each architecture, along with fixed and 10-year total equivalent system mass estimates relative to a reference case. System robustness is discussed in terms of the probability of no water or oxygen resupply as determined from the Monte Carlo simulations.
\end{abstract}

\section{Nomenclature}

$\begin{array}{ll}\mathrm{C}(\mathrm{s}) & =\text { carbon (solid) } \\ \mathrm{CEV} & =\text { Crew Exploration Vehicle } \\ \mathrm{CH}_{4} & =\text { methane } \\ \mathrm{CO}_{2} & =\text { carbon dioxide } \\ \mathrm{ELS} & =\text { Exploration Life Support } \\ \left(E_{\mathrm{M}}\right)_{\mathrm{LER}} & =\text { LER mobility equivalency without PUP, } \mathrm{kg} / \mathrm{kg} \\ \left(E_{\mathrm{M}}\right)_{\mathrm{LER}-\mathrm{PB}} & =\text { LER mobility equivalency with PUP and extra battery set, } \mathrm{kg} / \mathrm{kg} \\ \left(E_{\mathrm{P}}\right)_{\mathrm{PSU}-\mathrm{I}} & =\text { Outpost PSU illuminated-only (solar) power equivalency, } \mathrm{kg} / \mathrm{kW} \\ \left(E_{\mathrm{P}}\right)_{\mathrm{FSPS}} & =\text { Outpost FSPS continuous power equivalency, } \mathrm{kg} / \mathrm{kW} \\ \left(E_{\mathrm{P}}\right)_{\mathrm{LER}} & =\text { LER power equivalency without PUP }(\mathrm{LER} \mathrm{batteries} \text { only), } \mathrm{kg} / \mathrm{kW} \\ \left(E_{\mathrm{P}}\right)_{\mathrm{LER}-\mathrm{PB}} & =\text { LER/PUP power equivalency with extra battery set, } \mathrm{kg} / \mathrm{kW} \\ \mathrm{ESM} & =\text { Equivalent System Mass, kg } \\ \left(E_{\mathrm{T}}\right)_{\mathrm{PCM}} & =\text { Outpost PCM thermal equivalency, } \mathrm{kg} / \mathrm{kW} \\ \left(E_{\mathrm{T}}\right)_{\mathrm{LER}} & =\text { LER thermal equivalency, kg/kW } \\ \mathrm{EVA} & =\text { Extravehicular Activity } \\ \left(E_{\mathrm{V}}\right)_{\mathrm{PCM}} & =\text { Outpost PCM pressurized volume equivalency, } \mathrm{kg} / \mathrm{m}^{3} \\ \left(E_{\mathrm{V}}\right)_{\mathrm{PLM}} & =\text { Outpost PLM pressurized volume equivalency, } \mathrm{kg} / \mathrm{m}^{3} \\ \left(E_{\mathrm{V}}\right)_{\mathrm{PCC}} & =\text { LER PCC pressurized volume equivalency, } \mathrm{kg} / \mathrm{m}^{3} \\ f(x) & =\text { probability density function of } x \\ F(x) & =\text { cumulative distribution function of } x \\ \mathrm{FSPS} & =\text { Fission Surface Power System } \\ \mathrm{H}_{2} & =\text { hydrogen } \\ & \end{array}$

${ }^{1}$ Chemical Engineer, Science, Engineering, and Analysis Services Department, MC JE5EA.

${ }^{2}$ SIMA Element Lead, Crew and Thermal Systems Division, MC EC3. 


$\begin{array}{ll}\mathrm{H}_{2} \mathrm{O} & =\text { water } \\ \text { ISRU } & =\text { In Situ Resource Utilization } \\ \text { ISS } & =\text { International Space Station } \\ \mathrm{LER} & =\text { Lunar Electric Rover } \\ \mathrm{LPCOR} & =\text { Low Power } \mathrm{CO}_{2} \text { Removal } \\ \mathrm{MPSWS} & =\text { Microwave Powered Solid Waste Stabilization and Water Recovery Unit } \\ \mathrm{N}_{2} & =\text { nitrogen } \\ \mathrm{O}_{2} & =\text { oxygen } \\ \text { PCC } & =\text { Pressurized Crew Cab (component of LER; attaches to Crew Mobility Chassis) } \\ \text { PCM } & =\text { Pressurized Core Module } \\ \text { PEM } & =\text { Pressurized Excursion Module } \\ \text { PLM } & =\text { Pressurized Logistics Module } \\ \text { PLSS } & =\text { Portable Life Support System } \\ \text { PSA } & =\text { Pressure-Swing Adsorption } \\ \text { PSU } & =\text { Power and Support Unit (solar/RFC power system) } \\ \text { PUP } & =\text { Portable Utility Pallet } \\ \text { RCA } & =\text { Rapid Cycling Amine } \\ \text { RCA-0 } & =\text { Rapid Cycling Amine with } 0 \% \text { water recuperation (same as RCA) } \\ \text { RCA-75 } & =\text { Rapid Cycling Amine }+ \text { water recuperator with } 75 \% \text { water recuperation } \\ \text { RCA-90 } & =\text { Rapid Cycling Amine }+ \text { water recuperator with } 90 \% \text { water recuperation } \\ \text { RFC } & =\text { Regenerative Fuel Cell } \\ \text { SIMA } & =\text { Systems Integration, Modeling and Analysis (an element within ELS) } \\ \text { SARD } & =\text { Surface Architecture Reference Document } \\ \text { TSA } & =\text { Temperature-Swing Adsorption } \\ x & =\text { distributed variable }\end{array}$

\section{Introduction}

A S scenarios for human space exploration continue to evolve, so must studies of optimal life support system architectures and technologies. This paper presents results of a life support architecture study based on a 2009 NASA lunar exploration scenario known as Scenario 12. The study was performed by the Systems Integration, Modeling and Analysis (SIMA) Element within NASA's Exploration Life Support (ELS) Project.

\section{A. Scenario 12}

Scenario 12 represents a combination of ideas from earlier NASA lunar exploration scenarios. It includes an Outpost at the Lunar South Pole comprised of larger fixed surface elements with attached pressurized rovers. Some larger elements can be mobilized for long excursions (60-90 days). The scenario places a high emphasis on surface mobility even at continuous human presence, with planning assuming roughly $50 \%$ of the time away from the Outpost on excursions. The scenario also includes both fission and solar/regenerative fuel cell (RFC) power sources at assembly complete. Two design approaches were considered for the larger habitation modules: horizontal cylindrical modules (Scenario 12.0.1) and vertical cylindrical modules (Scenario 12.1.0).

Makeup of the Scenario 12.0.1 Outpost is shown schematically in Fig. $1{ }^{1}$ The completed outpost includes a Pressurized Core Module (PCM), Pressurized Excursion Module (PEM), and Pressurized Logistics Module (PLM), each of similar size and structure, and 4 pressurized Lunar Electric Rovers (LER). Life support functionality will be distributed between the fixed and mobile elements. ${ }^{2}$ The PCM is assumed to house most of the regenerative life support equipment within the fixed Outpost, while each LER must independently support 2 crewmembers (4 in contingency) for durations up to 3 days alone and up to 14 days with an attached Portable Utility Pallet (PUP). The PUP includes additional consumables and batteries, as well as a solar panel. During excursions, the entire 4-person crew leaves the Outpost in 2 of the LER, leaving the other 2 LER attached to the Outpost.

Build-up sequences and operations/logistics planning concepts were developed by NASA for Scenarios 12.0.1 and 12.1.0. For the purpose of this study, Outpost assembly complete is assumed to occur with delivery of the Lander-Integrated Fission Surface Power System (FSPS) to the otherwise completed Outpost. The analysis begins with the first nominal resupply (cargo) mission after assembly complete, and is assumed to extend out beyond the planned sequence for a 10-year total period with the same relative frequency of crewed and cargo missions. Two crewed missions of 180-day duration are assumed per year (each with a crew of 4) and 5 cargo missions are assumed for every 7 crewed missions. 


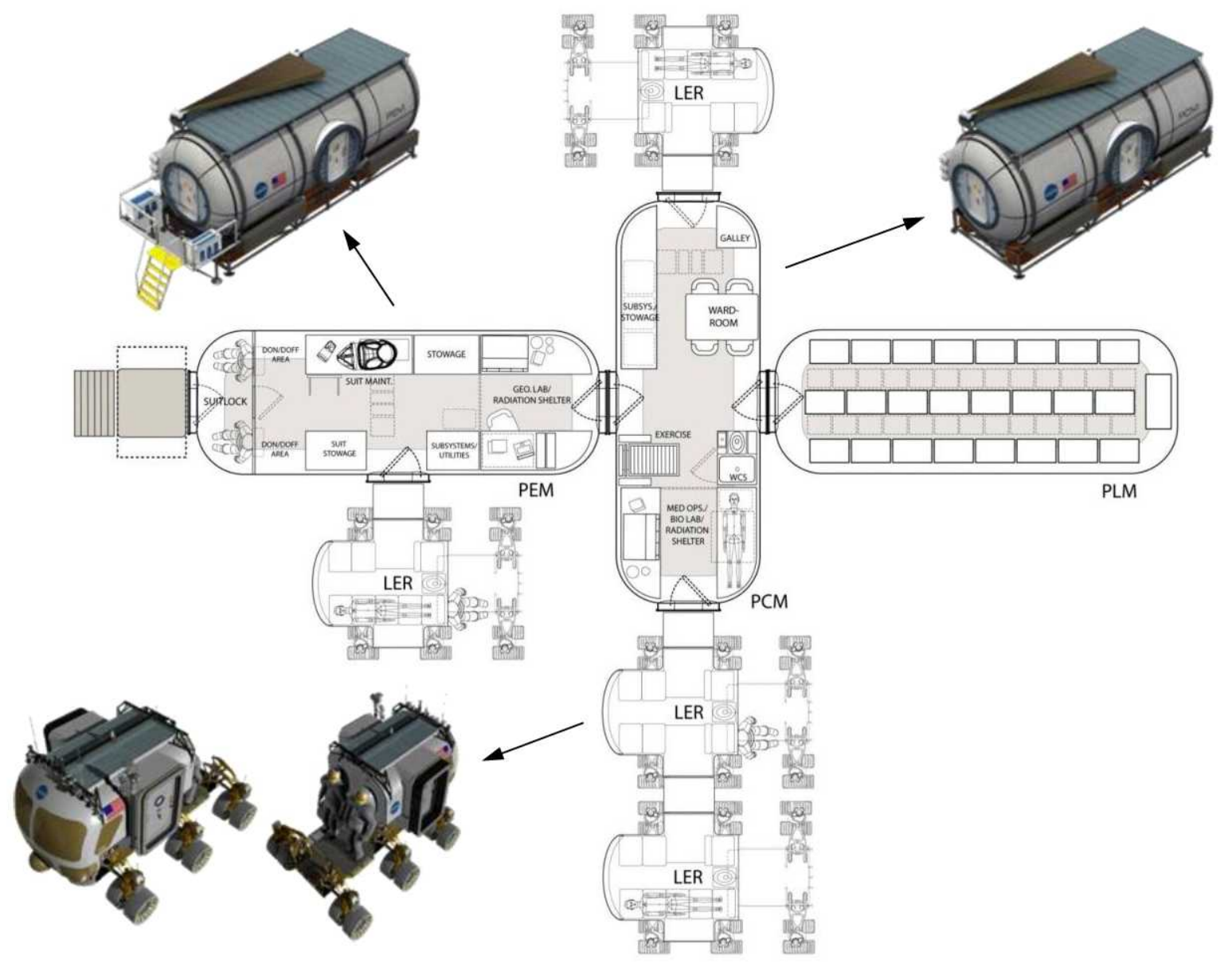

Figure 1. Scenario 12.0.1 Lunar Outpost schematic. Lunar Electric Rovers (LER) are shown without a Portable Utility Pallet (PUP).

Scenario12 planning concepts assume one to two 3-day excursions and six 14-day excursions per 180-day crewed mission after assembly complete. This translates into 87-90 total days on excursion per mission, or 48-50\% of the time on excursion. Planning results also indicate an assumption of 3 hours of extravehicular activity (EVA) per crewmember per day on excursion (average) with a lower EVA rate at the Outpost, classified as either "Utilization" or "Non-Utilization" EVA hours. The latter classification includes offloading, maintenance and critical action item tasks. Based on planning results for Scenarios 12.0.1 and 12.1.0, an average of 1320 total EVA hours (EVA hours per crewmember times the number of crewmembers) is assumed per 180-day mission after assembly complete. The high percentage of time on excursion and the delivery of 4 LER in Scenario 12 place a high emphasis on the size and functionality of the rover life support system and its optimal integration with fixed Outpost elements.

\section{B. Equivalent System Mass}

Equivalent System Mass (ESM) calculation is an approach that can be used to compare the overall launch mass impact of different life support technology or system architecture options. The approach accounts for the mass of life support equipment and supplies as well as associated "costs" of required infrastructure resources such as pressurized volume, power, and thermal control or cooling. Infrastructure cost factors are expressed in terms of mass equivalencies based on the total mass of the system that provides the resource and the total amount of the resource that the system provides. Infrastructure mass equivalencies for Scenario 12 elements were estimated from sizing results reported in the NASA "Surface Architecture Reference Document (SARD), Scenario 12.0.1," (Revision 4.1, August 14, 2009).

For this study, the total Outpost life support ESM was calculated using the following formulas, where the $\left(E_{i}\right)_{j}$ are mass equivalencies as defined in the Nomenclature section: 


$$
\begin{aligned}
\mathrm{ESM}_{\mathrm{TOTAL}} & =\mathrm{ESM}_{\mathrm{FIXED}}+\mathrm{ESM}_{\mathrm{RESUPPLY}} \\
\mathrm{ESM}_{\mathrm{FIXED}} & =\mathrm{ESM}_{\mathrm{PCM}}+4 \times \mathrm{ESM}_{\mathrm{LER}} \\
\mathrm{ESM}_{\mathrm{PCM}} & =\text { PCM Life Support Fixed Mass } \\
& +(\mathrm{PCM} \text { Life Support Pressurized Volume }) \times\left(E_{\mathrm{V}}\right)_{\mathrm{PCM}} \\
& +(\mathrm{PCM} \text { Life Support Continuous Power Requirement }) \times\left(E_{\mathrm{P}}\right)_{\mathrm{FSPS}} \\
& +(\mathrm{PCM} \text { Life Support Illuminated-Only Power Requirement }) \times\left(E_{\mathrm{P}}\right)_{\mathrm{PSU}-\mathrm{I}} \\
& +(\mathrm{PCM} \text { Life Support Cooling Requirement }) \times\left(E_{\mathrm{T}}\right)_{\mathrm{PCM}} \\
& =\{\text { LER Life Support Fixed Mass } \\
& +(\text { LER Life Support Pressurized Volume }) \times\left(E_{\mathrm{V}}\right)_{\mathrm{PCC}} \\
& +(\text { LER Life Support Power Requirement }) \times\left[\left(E_{\mathrm{P}}\right)_{\mathrm{LER}}+\left(E_{\mathrm{P}}\right)_{\mathrm{LER}-\mathrm{PB}}\right] / 2 \\
& \left.+(\text { LER Life Support Cooling Requirement }) \times\left(E_{\mathrm{T}}\right)_{\mathrm{LER}}\right\} \\
\mathrm{ESM}_{\mathrm{LER}} & \times\left[\left(E_{\mathrm{M}}\right)_{\mathrm{LER}}+\left(E_{\mathrm{M}}\right)_{\mathrm{LER}-\mathrm{PB}}\right] / 2 \\
& =\{\text { Life Support Consumable and Expendable Resupply Mass } / \text { year } \\
& + \text { Life Support Logistics and Spares Mass } / \text { year } \\
& + \text { Life-Support-Contributed Infrastructure Logistics and Spares Mass/year } \\
& \left.+[\text { Pressurized Volume of Resupplied Items } / \text { year }] \times\left(E_{\mathrm{V}}\right)_{\mathrm{PLM}}\right\} \\
& \times 10 \text { years } \\
\mathrm{ESM}_{\mathrm{RESUPPLY}} &
\end{aligned}
$$

Although the PEM and PLM will contain life support equipment for functions such as pressure control and ventilation, these contributions did not change with the architectures investigated in this study and thus were not included in the total." The LER ESM includes the normal stationary ESM total multiplied by a mobility equivalency that accounts for the "cost" of being able to transport the payload across the lunar surface (associated with the LER Crew Mobility Chassis and its share of the power system). For both the LER mobility equivalency and LER power equivalency, an average of the values obtained without the PUP and with the PUP and Extra Batteries was used, because only 2 of the 4 LER are assumed to go out on excursion at a time and require the PUP and Extra Batteries.

Yearly logistics and spares mass was generally assumed to be $5 \%$ of the life support fixed equipment mass and $5 \%$ of the associated infrastructure fixed power and thermal ESM. No logistics and spares mass was assumed for the LER thermal system (primarily a fusible heat sink or "ice block") or non-electrical components of the FSPS (including shielding). This logistics and spares estimation approach is similar to that used in Scenario 12 logistics planning.

Estimated volume, power, and thermal equivalencies for the LER were a factor 2 or more larger than the corresponding equivalencies for the fixed Outpost elements. The average mobility equivalency in Eq. (4) was estimated to be 1.4, further adding to the cost of mobile life support. At the fixed Outpost, the continuous power equivalency was estimated to be more than 5 times larger than the illuminated-only (solar) power equivalency, imposing a much higher power penalty on life support equipment that must operate continuously. These widely varying equivalencies suggest that the total impact of a distributed life support architecture in Scenario 12 will be highly dependent on equipment location and functionality. The use of the ESM approach in this context appears well suited for initial conceptual design studies where a primary goal is to identify promising architecture candidates that could substantially reduce launch mass. The relative impacts of mass, volume, power, and cooling "costs" for the LER and overall Outpost are reflected in ESM breakdown results presented later.

\footnotetext{
${ }^{*}$ Results are presented relative to a reference case, so that like contributions cancel.
} 


\section{Monte Carlo Simulations}

Monte Carlo simulations were used in this study to investigate the sensitivity of both mass balance and ESM results to potential variations and uncertainties in the following mission variables:

1) Habitat Air Leakage Rate, \%/day

2) Total EVA Hours per 180-day Crewed Mission, person-hr

3) Fraction of Surface Time on Excursion

4) Available Residual Oxygen from Landers per 180-day Crewed Mission, kg

These variables were selected because mass balance results indicated that they could have a high impact on the required degree of system closure to avoid water or oxygen resupply, and because alternative scenarios, requirement limits, and feasibility questions currently allow a large range of their potential values.

The Monte Carlo simulations were conducted by generating four random values between 0 and 1 for each simulation trial using the Microsoft ${ }^{\circ}$ Excel RAND() function and equating them to the values of the assumed cumulative probability distribution functions for the four mission variables. Corresponding values of the mission variables were then obtained by solving the inverse distribution functions. These values served as inputs to system mass balance and sizing calculations. Each architecture case included 5000 Monte Carlo simulation trials.

The selection of distribution functions for the four mission variables is clearly subjective in nature at this time. Distribution functions for this study were selected based on simplicity and proper limiting behavior (non-negative values; finite or infinite upper bound). A log-normal distribution (infinite upper bound) was selected for the habitat air leakage rate, and triangular distributions (finite upper bound) were selected for the other variables. In each case, the distribution parameters were adjusted so that the mode (peak of the probability density function) corresponds to the current assumption or best-estimate for Scenario 12. The assumed probability density functions and corresponding cumulative distribution functions are shown in Figs. 2 and 3, respectively.
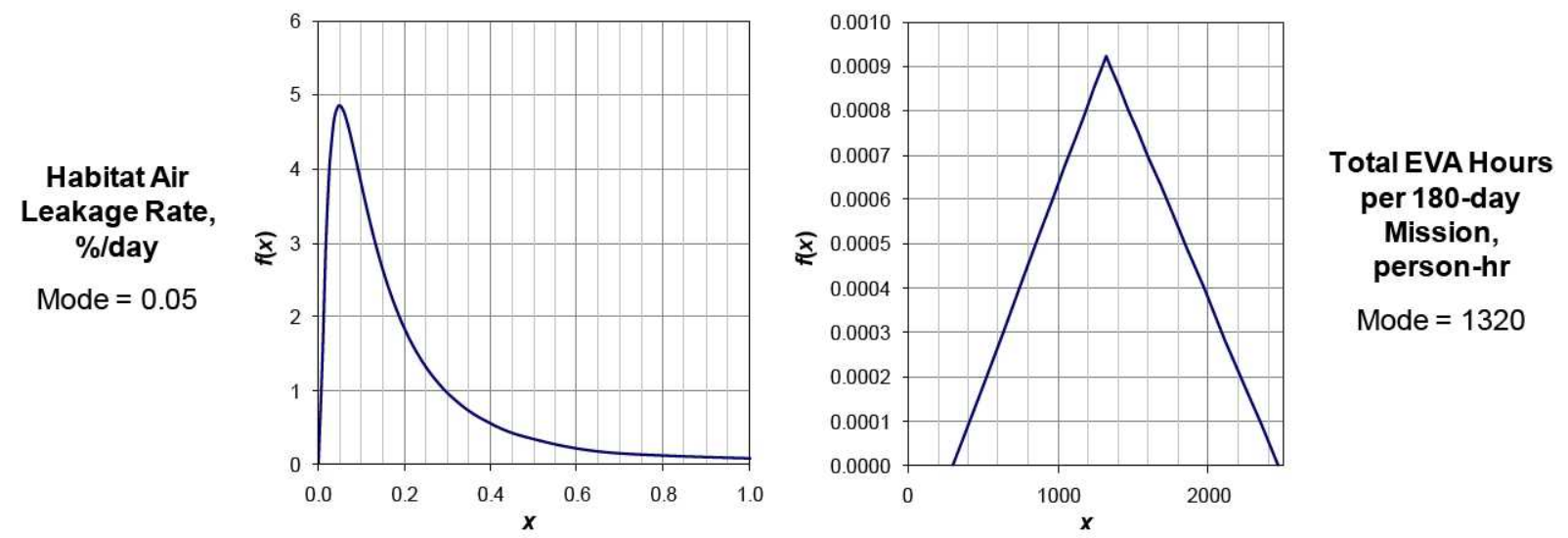

Mode $=1320$
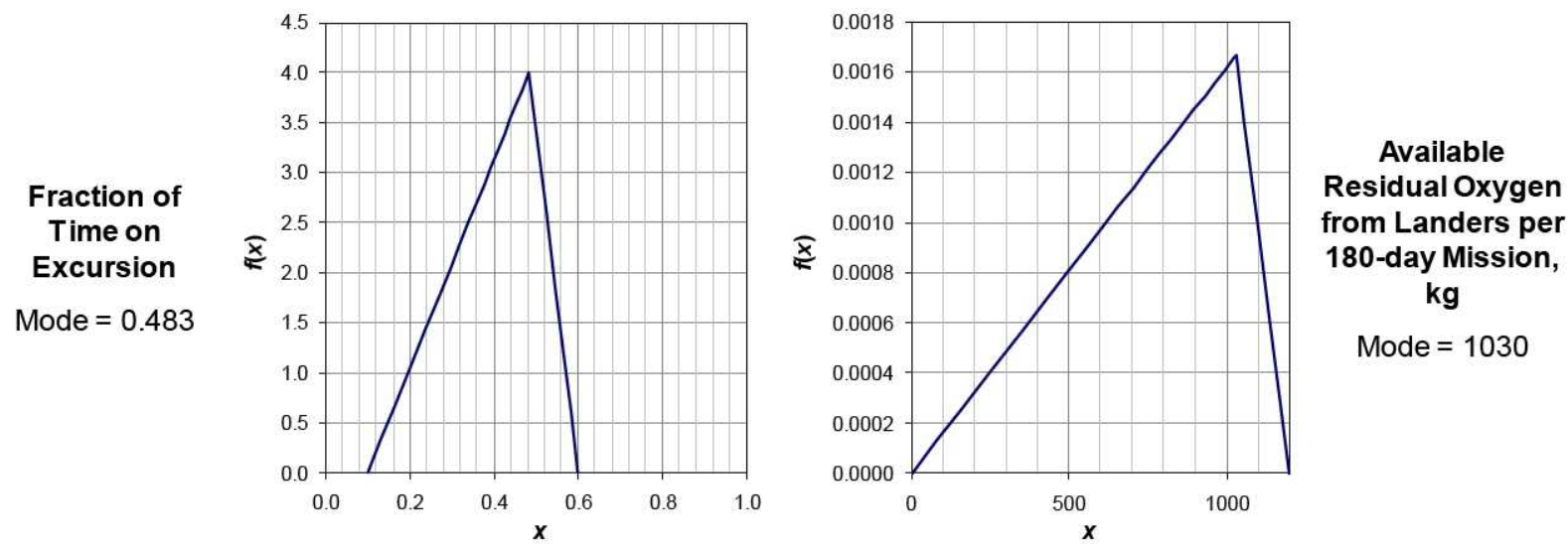

Mode $=1030$

Figure 2. Assumed probability density functions for Monte Carlo simulations. 

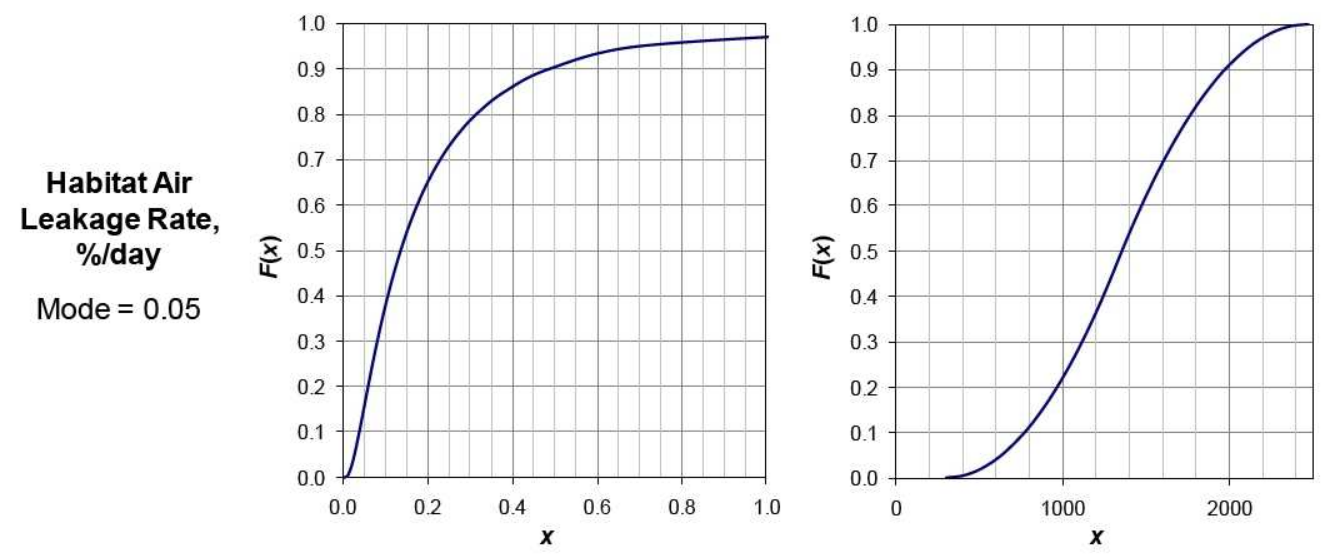
Total EVA Hours
per 180-day
Mission,
person-hr

Mode $=1320$
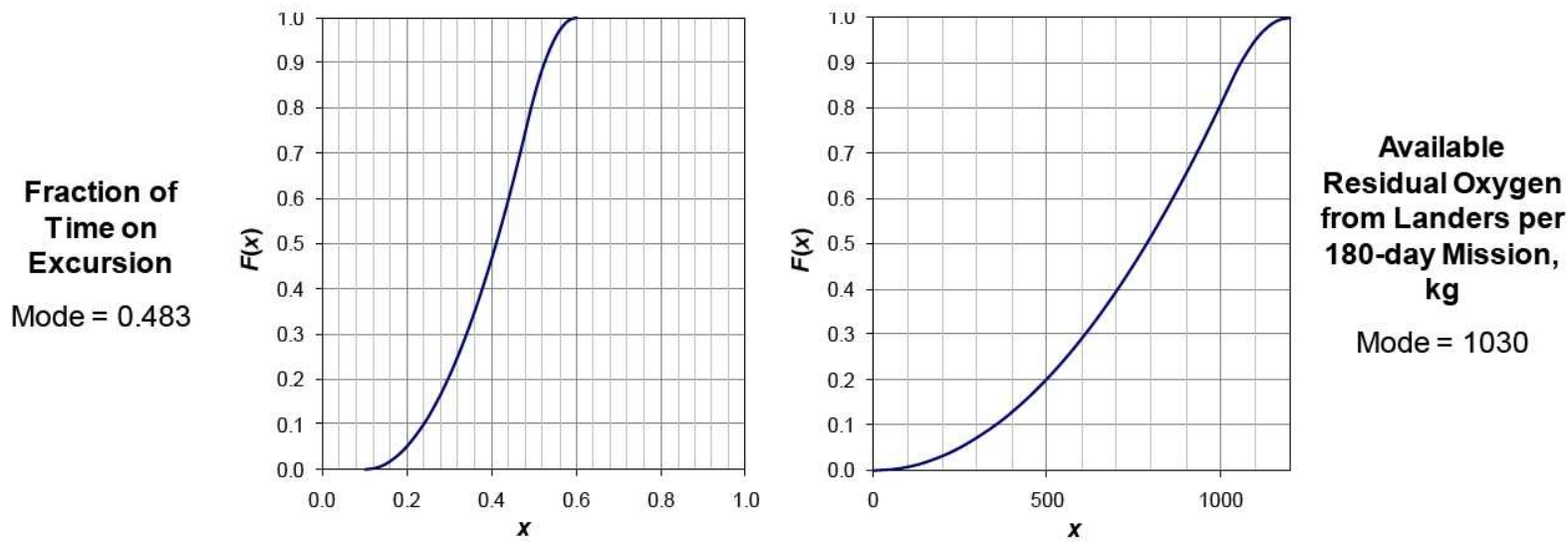

Mode $=1030$

Figure 3. Assumed cumulative distribution functions for Monte Carlo simulations.

The habitat air leakage rate distribution parameters were chosen so that there is a $10 \%$ probability that the leakage rate will be more than an order of magnitude larger than the Scenario 12 assumption ( $0.05 \%$ /day). This "high-end" uncertainty was taken to reflect the unknown impact of lunar dust and frequent mating/de-mating on hatch and mating adapter sealing.

The upper bound on total EVA hours corresponds to an EVA Element Ground Rule of a maximum of 24 hours of EVA per crewmember per week for missions greater than 7 days. The lower bound reflects a minimal number of EVA hours.

The bounds on the fraction of time on excursion were taken to reflect the desire to utilize the mobility capabilities of the Outpost design, while justifying the existence of the fixed Outpost elements. The upper bound of 0.6 was therefore taken to be only a little greater than that assumed in Scenario 12 .

In contrast to the other variables, the mode of the distribution for available residual oxygen from Landers was not completely derived from the NASA Scenario 12 analysis, but was partially estimated using results from a recent paper on Lander propellant scavenging by Linne and coworkers. ${ }^{3}$ The mode accounts for the relative frequency of crewed and cargo missions in Scenario 12 discussed earlier. The upper bound of the distribution reflects a higher one-to-one ratio of crewed and cargo missions.

As discussed in the next section, different options could exist for recovering residual Lander propellants, including direct recovery of oxygen and hydrogen, as well as conversion of oxygen and hydrogen to water. For Monte Carlo simulations involving each of these options, the residual oxygen distribution is used along with a fixed ratio of hydrogen $\left(0.248 \mathrm{~kg} \mathrm{H}_{2} / \mathrm{kg} \mathrm{O}_{2}\right.$, based on Ref. 3) and the water formation stoichiometry to determine the available quantities of each recovered resource. 


\section{Scavenging Options}

Four scavenging options were considered in this study:

1) $\mathbf{H}_{2} \mathrm{O}$ : Residual cryogenic propellant oxygen and hydrogen are converted to water using Lander fuel cells or by a controlled catalytic reaction. Life support receives the generated water.

2) $\mathbf{H}_{2} \mathbf{O} / \mathbf{H}_{2}$ : Same as Option 1, but life support also receives excess residual hydrogen (oxygen is the limiting reactant for water production).

3) $\mathbf{O}_{2} / \mathbf{H}_{2} \mathbf{O}$ : Life support first receives residual oxygen up to the amount required by life support. Remaining residuals are then converted to water for life support.

4) $\mathbf{O}_{2} / \mathbf{H}_{2} \mathbf{O} / \mathbf{H}_{2}$ : Same as Option 3, but life support also receives excess residual hydrogen.

Considerable uncertainty currently exists as to the recoverable quantities of residual propellants (pending design of the Lander propellant feed system) and losses involved in alternative recovery operations. Recent studies ${ }^{3,4}$ have focused on water recovery, noting its more easy storage and potential difficulties in extracting the residual cryogenic liquids. It is not clear, however, whether a strong system-level advantage to direct oxygen and hydrogen recovery, if found, could alter this focus or drive the design of the propellant feed and storage system to more easily accommodate such recovery.

\section{E. Life Support Technology Options and Architecture Case Definitions}

Life support technology options for this study were selected to provide a representative range of potential life support architectures with varying degrees of system closure and distributed functionality. These options are described in Table 1. The technologies chosen were generally those that traded well in earlier studies or that reflect the range of expected performance behavior within a functional area. Alternative technologies exist at various levels of development that could provide savings in ESM, improved reliability, or other benefits.

Table 1. Life Support Options and Assumptions

\begin{tabular}{|c|c|c|}
\hline Function & Option & Description and Assumptions \\
\hline \multirow[b]{2}{*}{$\mathrm{CO}_{2}$ Removal } & $\begin{array}{l}\text { Rapid Cycling Amine } \\
\text { (RCA) with or } \\
\text { without Water } \\
\text { Recuperator }\end{array}$ & $\begin{array}{l}\text { - PSA system using supported liquid amine. } \\
\text { - Vents } \mathrm{CO}_{2} \text { and } \mathrm{H}_{2} \mathrm{O} \text { vapor to space vacuum (recuperator reduces } \mathrm{H}_{2} \mathrm{O} \text { loss). } \\
\text { - EVA PLSS baseline (without recuperator); similar to Orion CEV technology. } \\
\text { - } \mathrm{H}_{2} \mathrm{O} \text { recuperator sizing estimated based on membrane technology. }\end{array}$ \\
\hline & $\begin{array}{l}\text { Low-Power } \mathrm{CO}_{2} \\
\text { Removal (LPCOR) }\end{array}$ & $\begin{array}{l}\text { - 2-stage molecular-sieve-based TSA/PSA system designed for } \mathrm{CO}_{2} \text { recovery. } \\
\text { - ELS development technology with ISS heritage; } 100 \% \text { water recuperation. } \\
\text { - } \mathrm{CO}_{2} \text { compressor/liquefier and tank added for } \mathrm{CO}_{2} \text { storage on excursion when selected for } \\
\text { LER with } \mathrm{CO}_{2} \text { reduction at Outpost (rough estimate); no } \mathrm{CO}_{2} \text { storage assumed at } \\
\text { Outpost. }\end{array}$ \\
\hline \multirow[b]{2}{*}{$\mathrm{CO}_{2}$ Reduction } & Sabatier & - $\mathrm{CO}_{2}+4 \mathrm{H}_{2} \leftrightarrow \mathrm{CH}_{4}+2 \mathrm{H}_{2} \mathrm{O}\left(4\right.$ moles of $\mathrm{H}_{2}$ required per mole of $\left.\mathrm{CO}_{2}\right)$ \\
\hline & Bosch & $\begin{array}{l}\text { - } \mathrm{CO}_{2}+2 \mathrm{H}_{2} \leftrightarrow \mathrm{C}(\mathrm{s})+2 \mathrm{H}_{2} \mathrm{O}\left(2 \text { moles of } \mathrm{H}_{2} \text { required per mole of } \mathrm{CO}_{2}\right) \\
\text { - Requires recycle; expendable catalyst/carbon cartridge. }\end{array}$ \\
\hline $\mathrm{O}_{2}$ Generation & $\mathrm{H}_{2} \mathrm{O}$ Electrolysis & $\begin{array}{l}\text { - High-pressure } \mathrm{H}_{2} \mathrm{O} \text { electrolysis with } \mathrm{O}_{2} \text { and } \mathrm{H}_{2} \text { storage assumed; ESM estimates based } \\
\text { on proposed regenerative fuel cell components; could also use low-pressure electrolysis } \\
\text { (similar to ISS system) with subsequent compression. } \\
\text { - } \mathrm{H}_{2} \text { storage (28-days assumed capacity) used during excursions when necessary to allow } \\
\text { continuous } \mathrm{O}_{2} \text { generation at Outpost at mission average rate; traded better than regulating } \\
\mathrm{O}_{2} / \mathrm{H}_{2} \text { generation to maximize } \mathrm{CO}_{2} \text { reduction and allows greater system flexibility. } \\
\text { - Key assumption in mass balance is that all oxygen requirements are met by the } \\
\text { electrolysis system when selected. }\end{array}$ \\
\hline \multirow[t]{2}{*}{$\mathrm{H}_{2} \mathrm{O}$ Recovery } & $\begin{array}{l}\text { Generic (distillation }+ \\
\text { post processing) } \mathrm{H}_{2} \mathrm{O} \\
\text { recovery with typical } \\
\text { recovery percentages }\end{array}$ & $\begin{array}{l}\text { - Assumed } \mathrm{H}_{2} \mathrm{O} \text { recovery percentages for mass balance: } 85 \% \text { for urine/flush water; } \sim 100 \% \\
\text { for humidity condensate. } \\
\text { - Potential differences in water recovery system sizing between cases not currently } \\
\text { included in ESM analysis. }\end{array}$ \\
\hline & $\begin{array}{l}\text { Varying levels of } \\
\text { brine/solid-waste } \\
\text { water recovery }\end{array}$ & $\begin{array}{l}\text { - Baseline for study is } 90 \% \text { brine } \mathrm{H}_{2} \mathrm{O} \text { recovery and } 50 \% \text { solid-waste } \mathrm{H}_{2} \mathrm{O} \text { recovery. } \\
\text { - ESM estimates based on optimized Microwave Powered Solid Waste Stabilization and } \\
\text { Water Recovery Unit (MPSWS) as described by Fisher and coworkers. }{ }^{5}\end{array}$ \\
\hline \multirow{2}{*}{$\begin{array}{l}\text { Packaged Food } \\
\text { Supply }\end{array}$} & Low Moisture & $\begin{array}{l}\text { - Provides } 0.26 \mathrm{~kg} / \text { person } / \text { day of } \mathrm{H}_{2} \mathrm{O} \text { in food (before rehydration) for a } 12,000 \mathrm{~kJ} / \mathrm{day} \\
\text { diet; baseline for study. }\end{array}$ \\
\hline & Nominal Moisture & $\begin{array}{l}\text { - Provides } 0.5 \mathrm{~kg} / \text { person/day of } \mathrm{H}_{2} \mathrm{O} \text { in food (before rehydration) for a } 12,000 \mathrm{~kJ} / \text { day diet. } \\
\text { - Similar to ISS and Shuttle food system. }\end{array}$ \\
\hline
\end{tabular}


Table 2 defines the life support architecture cases examined in this study. The cases differ in the type of $\mathrm{CO}_{2}$ removal system used on excursion (in the LER) and at the Outpost, the use of $\mathrm{H}_{2} \mathrm{O}$ electrolysis for $\mathrm{O}_{2}$ generation, the use and type of $\mathrm{CO}_{2}$ reduction, and the type of Lander resource scavenging employed. The letter " $\mathrm{B}$ " or " $\mathrm{S}$ " following the case number indicates Bosch or Sabatier $\mathrm{CO}_{2}$ reduction, respectively. The absence of a letter following the case number indicates no $\mathrm{CO}_{2}$ reduction.

Table 2. Architecture Study Case Definitions

\begin{tabular}{|c|c|c|c|c|c|c|c|}
\hline Case & $\begin{array}{c}\mathrm{CO}_{2} \\
\text { Removal } \\
\text { System on } \\
\text { Excursion }\end{array}$ & $\begin{array}{c}\mathrm{CO}_{2} \\
\text { Removal } \\
\text { System at } \\
\text { Outpost }\end{array}$ & $\begin{array}{c}\mathrm{O}_{2} \\
\text { Generation } \\
\text { at Outpost }\end{array}$ & $\begin{array}{c}\mathrm{CO}_{2} \\
\text { Reduction at } \\
\text { Outpost }\end{array}$ & $\begin{array}{l}\text { Scavenged } \\
\text { Lander } \\
\text { Resources }\end{array}$ & $\begin{array}{c}\text { Scenario 12 } \\
\mathrm{H}_{2} / \mathrm{CO}_{2} \text { Molar } \\
\text { Ratio for } \mathrm{CO}_{2} \\
\text { Reduction }\end{array}$ & Description \\
\hline 1B & LPCOR & LPCOR & Electrolysis & Bosch & $\mathrm{H}_{2} \mathrm{O}$ & 2.7 & \multirow{6}{*}{$\begin{array}{l}\text { Group 1: } \mathrm{CO}_{2} \text { recovery on } \\
\text { excursion and at outpost with } \\
\text { LER systems ( } 100 \% \mathrm{H}_{2} \mathrm{O} \\
\text { recuperation). }\end{array}$} \\
\hline 1S & LPCOR & LPCOR & Electrolysis & Sabatier & $\mathrm{H}_{2} \mathrm{O}$ & 2.7 & \\
\hline $2 \mathrm{~S}$ & LPCOR & LPCOR & Electrolysis & Sabatier & $\mathrm{H}_{2} \mathrm{O} / \mathrm{H}_{2}$ & 6.7 & \\
\hline $3 \mathrm{~B}$ & LPCOR & LPCOR & None & Bosch & $\mathrm{O}_{2} / \mathrm{H}_{2} \mathrm{O} / \mathrm{H}_{2}$ & 6.7 & \\
\hline $3 \mathrm{~S}$ & LPCOR & LPCOR & None & Sabatier & $\mathrm{O}_{2} / \mathrm{H}_{2} \mathrm{O} / \mathrm{H}_{2}$ & 6.7 & \\
\hline 4 & LPCOR & LPCOR & None & None & $\mathrm{O}_{2} / \mathrm{H}_{2} \mathrm{O}$ & 0.0 & \\
\hline $5 \mathrm{~B}$ & RCA-90 & LPCOR & Electrolysis & Bosch & $\mathrm{H}_{2} \mathrm{O}$ & 5.0 & \multirow{6}{*}{$\begin{array}{l}\text { Group 2: } \mathrm{CO}_{2} \text { venting on } \\
\text { excursion with } 90 \% \mathrm{H}_{2} \mathrm{O} \\
\text { recuperation; } \mathrm{CO}_{2} \text { recovery a } \\
\text { outpost with separate system. }\end{array}$} \\
\hline $5 \mathrm{~S}$ & RCA-90 & LPCOR & Electrolysis & Sabatier & $\mathrm{H}_{2} \mathrm{O}$ & 5.0 & \\
\hline $6 \mathrm{~S}$ & RCA-90 & LPCOR & Electrolysis & Sabatier & $\mathrm{H}_{2} \mathrm{O} / \mathrm{H}_{2}$ & 12.4 & \\
\hline $7 \mathrm{~B}$ & RCA-90 & LPCOR & None & Bosch & $\mathrm{O}_{2} / \mathrm{H}_{2} \mathrm{O} / \mathrm{H}_{2}$ & 12.4 & \\
\hline $7 \mathrm{~S}$ & RCA-90 & LPCOR & None & Sabatier & $\mathrm{O}_{2} / \mathrm{H}_{2} \mathrm{O} / \mathrm{H}_{2}$ & 12.4 & \\
\hline 8 & RCA-90 & LPCOR & None & None & $\mathrm{O}_{2} / \mathrm{H}_{2} \mathrm{O}$ & 0.0 & \\
\hline $9 \mathrm{~B}$ & RCA-75 & LPCOR & Electrolysis & Bosch & $\mathrm{H}_{2} \mathrm{O}$ & 5.0 & \multirow{6}{*}{$\begin{array}{l}\text { Group 3: } \mathrm{CO}_{2} \text { venting on } \\
\text { excursion with } 75 \% \mathrm{H}_{2} \mathrm{O} \\
\text { recuperation; } \mathrm{CO}_{2} \text { recovery a } \\
\text { outpost with separate system. }\end{array}$} \\
\hline $9 S^{*}$ & RCA-75 & LPCOR & Electrolysis & Sabatier & $\mathrm{H}_{2} \mathrm{O}$ & 5.0 & \\
\hline $10 \mathrm{~S}$ & RCA-75 & LPCOR & Electrolysis & Sabatier & $\mathrm{H}_{2} \mathrm{O} / \mathrm{H}_{2}$ & 12.4 & \\
\hline $11 \mathrm{~B}$ & RCA-75 & LPCOR & None & Bosch & $\mathrm{O}_{2} / \mathrm{H}_{2} \mathrm{O} / \mathrm{H}_{2}$ & 12.4 & \\
\hline $11 \mathrm{~S}$ & RCA-75 & LPCOR & None & Sabatier & $\mathrm{O}_{2} / \mathrm{H}_{2} \mathrm{O} / \mathrm{H}_{2}$ & 12.4 & \\
\hline 12 & RCA-75 & LPCOR & None & None & $\mathrm{O}_{2} / \mathrm{H}_{2} \mathrm{O}$ & 0.0 & \\
\hline $13 \mathrm{~B}$ & RCA-0 & LPCOR & Electrolysis & Bosch & $\mathrm{H}_{2} \mathrm{O}$ & 5.0 & \multirow{6}{*}{$\begin{array}{l}\text { Group 4: } \mathrm{CO}_{2} \text { venting on } \\
\text { excursion with no } \mathrm{H}_{2} \mathrm{O} \\
\text { recuperation; } \mathrm{CO}_{2} \text { recovery a } \\
\text { outpost with separate system. }\end{array}$} \\
\hline $13 \mathrm{~S}$ & RCA- 0 & LPCOR & Electrolysis & Sabatier & $\mathrm{H}_{2} \mathrm{O}$ & 5.0 & \\
\hline $14 \mathrm{~S}$ & RCA-0 & LPCOR & Electrolysis & Sabatier & $\mathrm{H}_{2} \mathrm{O} / \mathrm{H}_{2}$ & 12.4 & \\
\hline $15 \mathrm{~B}$ & RCA- 0 & LPCOR & None & Bosch & $\mathrm{O}_{2} / \mathrm{H}_{2} \mathrm{O} / \mathrm{H}_{2}$ & 12.4 & \\
\hline $15 \mathrm{~S}$ & RCA- 0 & LPCOR & None & Sabatier & $\mathrm{O}_{2} / \mathrm{H}_{2} \mathrm{O} / \mathrm{H}_{2}$ & 12.4 & \\
\hline 16 & RCA-0 & LPCOR & None & None & $\mathrm{O}_{2} / \mathrm{H}_{2} \mathrm{O}$ & 0.0 & \\
\hline 17 & RCA-90 & RCA-90 & None & None & $\mathrm{O}_{2} / \mathrm{H}_{2} \mathrm{O}$ & 0.0 & \multirow{3}{*}{$\begin{array}{l}\text { Group 5: } \mathrm{CO}_{2} \text { venting on } \\
\text { excursion and at outpost with } \\
\text { LER systems. }\end{array}$} \\
\hline 18 & RCA-75 & RCA-75 & None & None & $\mathrm{O}_{2} / \mathrm{H}_{2} \mathrm{O}$ & 0.0 & \\
\hline 19 & RCA-0 & RCA- 0 & None & None & $\mathrm{O}_{2} / \mathrm{H}_{2} \mathrm{O}$ & 0.0 & \\
\hline
\end{tabular}

*Reference case.

Cases are grouped by $\mathrm{CO}_{2}$ removal options and reflect different levels of $\mathrm{CO}_{2}$ and $\mathrm{H}_{2} \mathrm{O}$ recovery from the cabin atmosphere on excursion and at the Outpost. Group 1 uses the LPCOR technology on the LER to recover $\mathrm{CO}_{2}$ and $\mathrm{H}_{2} \mathrm{O}$ (as humidity condensate) both on excursion and at the Outpost. Group 2 uses the RCA technology on the LER with a $90 \%$ effective $\mathrm{H}_{2} \mathrm{O}$ recuperator. $\mathrm{CO}_{2}$ removed on excursion is thus vented, while most of the $\mathrm{H}_{2} \mathrm{O}$ vapor is recovered as humidity condensate. A separate LPCOR system is used at the Outpost (in the PCM) to recover $\mathrm{CO}_{2}$ and $\mathrm{H}_{2} \mathrm{O}$ generated when the crew is present. Groups 3and 4 are similar to Group 2, but with decreasing levels of $\mathrm{H}_{2} \mathrm{O}$ vapor recovery on excursion. Group 5 reflects common $\mathrm{CO}_{2}$ venting options both on excursion and at the Outpost. For cases where the LPCOR system is used without $\mathrm{CO}_{2}$ reduction at the Outpost (Cases 4, 8, 12, and 16), the recoverable $\mathrm{CO}_{2}$ is vented.

The seventh column of Table 2 shows calculated molar ratios of generated and scavenged $\mathrm{H}_{2}$ to recovered $\mathrm{CO}_{2}$ based on Scenario 12 assumptions and can be compared with the stoichiometric requirements for $\mathrm{CO}_{2}$ reduction reported in Table 1. For Monte Carlo simulations, these ratios will vary.

All of the cases in Table 2 were run with a baseline set of additional options that included low-moisture food, $90 \%$ brine water recovery, and $50 \%$ water recovery from solid wastes. These cases are referred to as "baseline cases" in the descriptions that follow. Cases were also run with nominal moisture food (not discussed in this paper) 
and different levels of brine and solid waste water recovery. For all cases, humidity condensate, urine/flush water, and solid wastes collected on excursion are assumed to be returned to the Outpost for processing. Case 9S with the baseline option set was used as the reference case for all ESM comparisons. This case is believed to be similar to that in NASA's working baseline design.

Figure 4 compares the $\mathrm{CO}_{2}$ removal hardware distribution at the Outpost for the different architecture groups. The LER systems are assumed to provide $\mathrm{CO}_{2}$ removal for the Outpost when a separate system is not provided in the PCM. Otherwise, the LER systems provide backup capability at the Outpost.

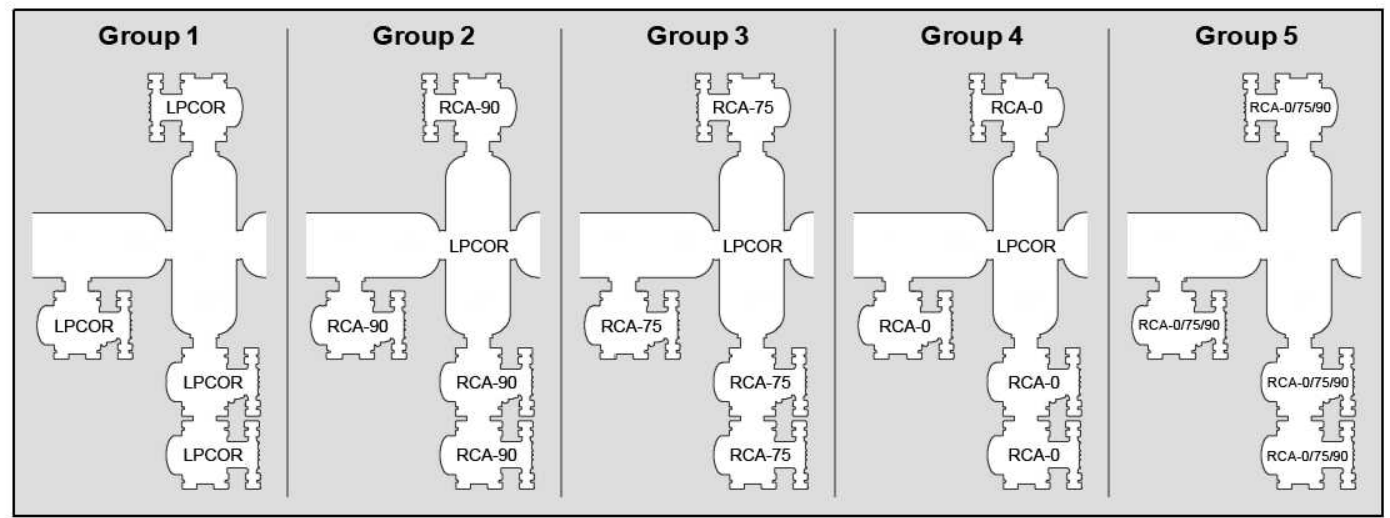

Figure 4. $\mathrm{CO}_{2}$ removal hardware distribution at Outpost for different architecture groups.

\section{Results}

\section{A. Mass Balance Results for Baseline Cases}

Water and oxygen balance results for each of the baseline cases are shown in Figs. 5 and 6, respectively. From Fig. 5, it can be seen that most of the cases achieve a positive water balance based on current Scenario 12 assumptions (Scenario 12 results) due largely to the high level of propellant scavenging from both crewed and cargo missions. These include cases with water scavenging and electrolysis as well as cases with oxygen scavenging and no electrolysis. As expected, the water surplus increases with higher water vapor recovery on excursion and with $\mathrm{CO}_{2}$ reduction.

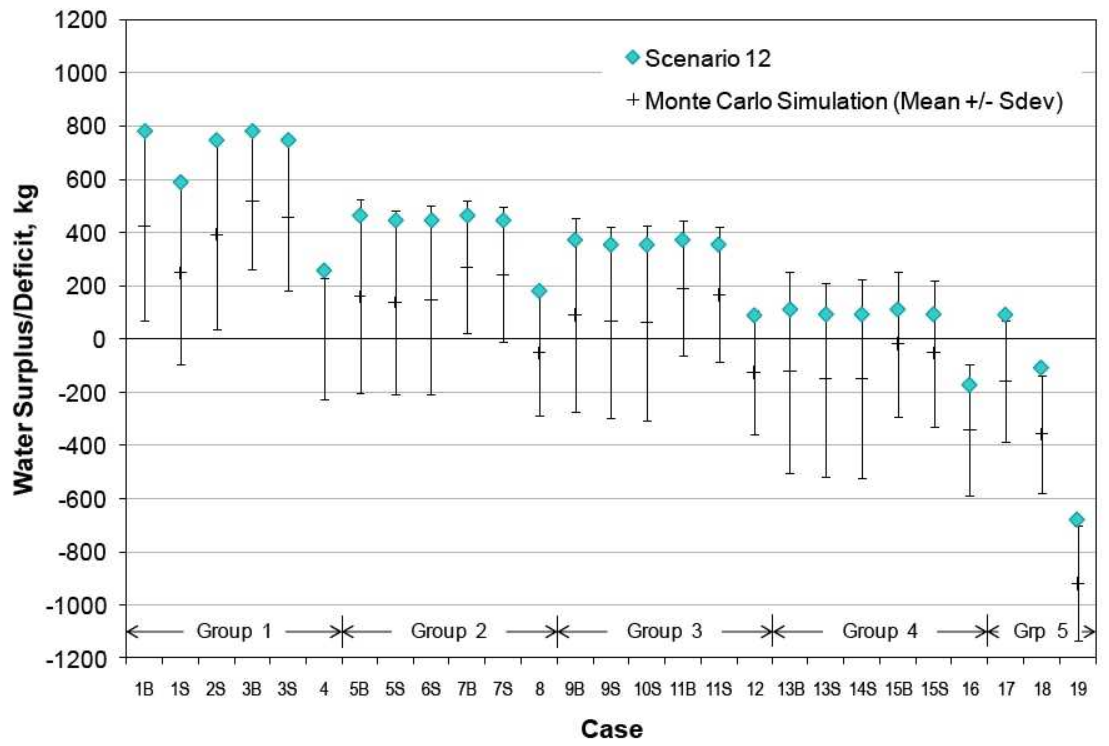

Figure 5. Water surplus (positive) or deficit (negative) per 180-day crewed mission for baseline cases. Results from current Scenario 12 assumptions are compared with results (mean \pm standard deviation) from Monte Carlo simulations with distributed mission variables. 


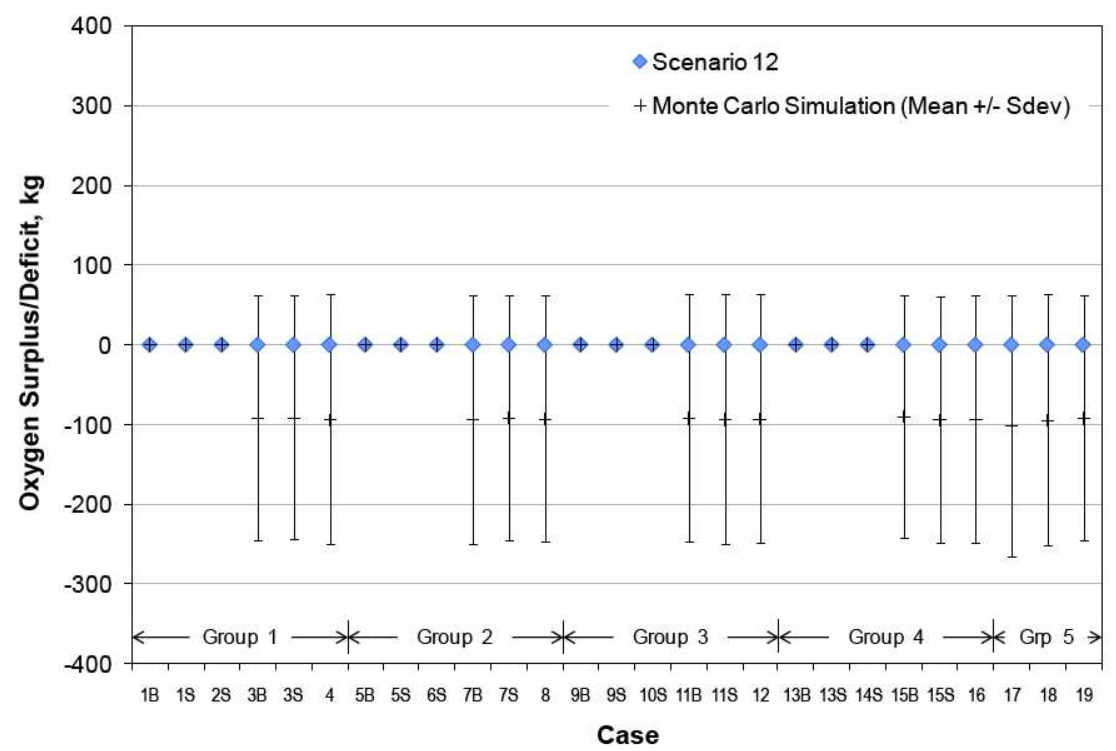

Figure 6. Oxygen surplus (positive) or deficit (negative) per 180-day crewed mission for baseline cases. Results from current Scenario 12 assumptions are compared with results (mean \pm standard deviation) from Monte Carlo simulations with distributed mission variables.

By comparison, results from Monte Carlo simulations in Fig. 5 show a high sensitivity to mission assumptions with only the highest closure cases $(1 \mathrm{~B}, 2 \mathrm{~S}, 3 \mathrm{~B}, 3 \mathrm{~S}$, and $7 \mathrm{~B})$ providing a water surplus within one standard deviation of the mean. The trend to a more negative water balance can be attributed largely to the lower level of scavenging obtained on average from the assumed distribution function for available residual oxygen (see Figs. 2 and 3).

From Fig. 6, it can be seen that sufficient generated and scavenged resources are available to meet the oxygen requirement for all of the Scenario 12 cases. The mass balance algorithm assumes that any excess resources are converted to water, so an oxygen surplus is not observed. By comparison, Monte Carlo simulations for cases with direct oxygen scavenging and no electrolysis indicate the potential for an oxygen deficit that is attributable to the level of scavenging being insufficient to meet requirements.

\section{B. Sensitivity to Brine/Solid-Waste Water Recovery}

Fig. 7 compares the Scenario 12 water balance for selected cases as a function of the level of brine and solidwaste water recovery. Low moisture food is used as in the baseline. The results show a significant impact on the water balance. For cases with low levels of $\mathrm{H}_{2} \mathrm{O}$ vapor recovery on excursion or no $\mathrm{CO}_{2}$ reduction, a higher level of water recovery from brine and solid waste can change the water balance from negative to positive. Conversely, for cases with high levels of $\mathrm{H}_{2} \mathrm{O}$ vapor recovery on excursion and $\mathrm{CO}_{2}$ reduction, a high level of water recovery from brine and solid waste may not be required to achieve a positive water balance, although it may be desirable for other reasons, such as waste stabilization and volume reduction.

Corresponding results from Monte Carlo simulations can be expressed in terms of the mean (expected value) and standard deviation of the water surplus/deficit as in Fig. 5. The simulations can also be used to estimate the probability that the system will require no water or oxygen resupply based on the fraction of trials meeting that criterion for each case. This probability provides a quantitative and comparative measure of system robustness under uncertainty in mission variables as defined by the assumed distribution functions. Results of the probability estimates are shown in Fig. 8. The level of brine and solid-waste water recovery can have a significant impact on the probability of no water or oxygen resupply, with incremental increases of 0.1 or more observed in some cases. In cases with less impact (such as $3 \mathrm{~S}$ ), the probability is more influenced by the oxygen balance than by the water balance. 


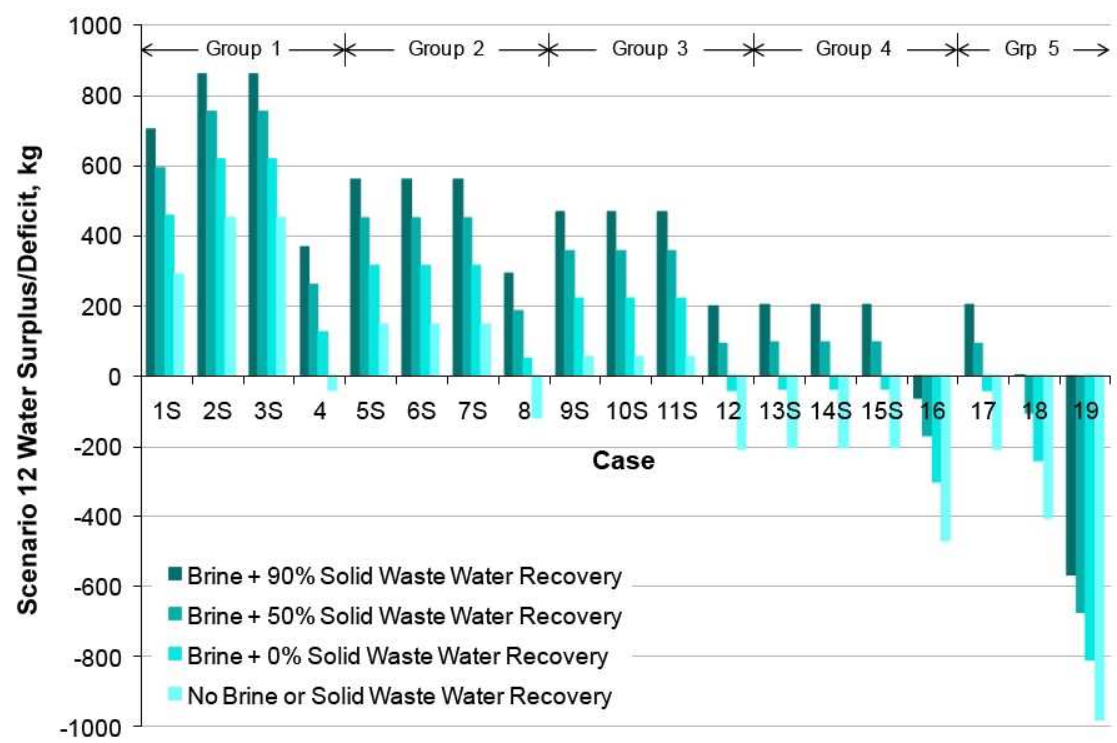

Figure 7. Water surplus (positive) or deficit (negative) per 180-day crewed mission for selected Scenario 12 cases as a function of the level of brine and solid-waste water recovery.

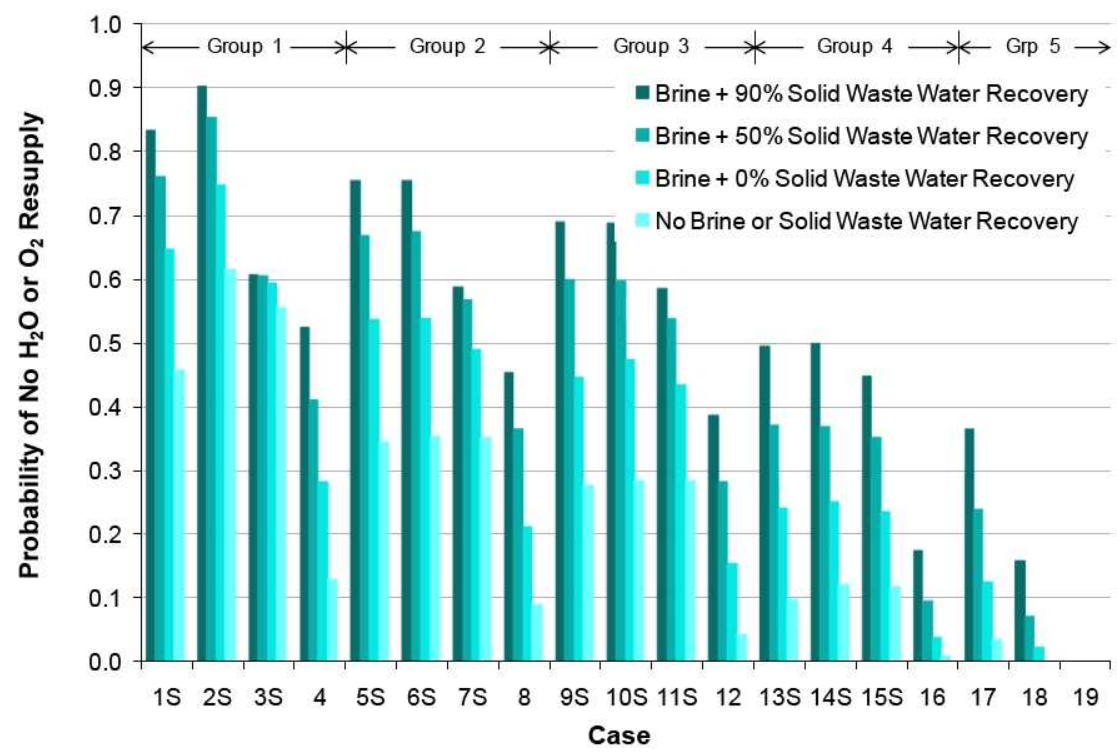

Figure 8. Probability of no water or oxygen resupply for selected cases as a function of the level of brine and solid-waste water recovery (from Monte Carlo simulations).

\section{ESM Results for Baseline Cases}

Equivalent System Mass results for each of the baseline cases are shown in Figs. 9 and 10. Fig. 9 compares the Outpost fixed ESM, which includes the ESM associated with fixed hardware in the 4 LER and the PCM, but not resupply items such as consumables, expendables and spares. It can be seen for Scenario 12 cases that the fixed ESM increases substantially with increasing system closure, particularly with respect to changes in the $\mathrm{CO}_{2}$ removal system on the LER. Monte Carlo simulation results show little difference from the Scenario 12 results, reflecting the 
relatively small impact of the distributed mission variables on equipment sizing. Much of the fixed equipment sizing (including $\mathrm{CO}_{2}$ removal and humidity control) is driven by maximum daily loads.

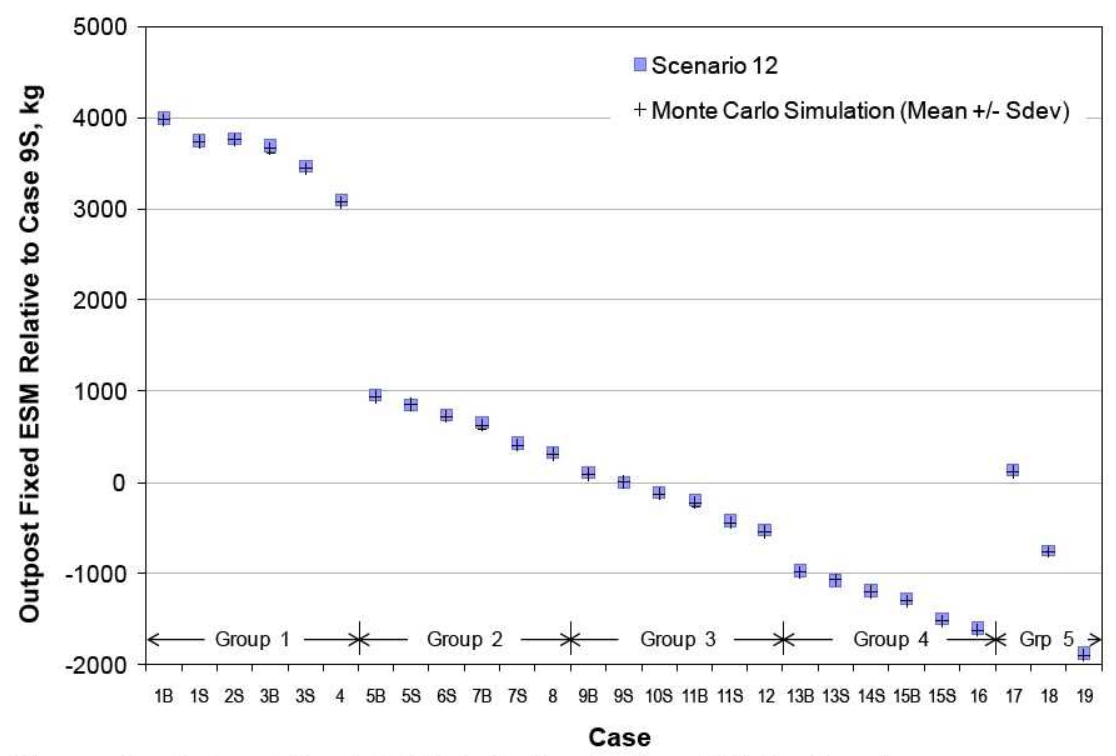

Figure 9. Outpost fixed ESM (relative to Case 9S) for baseline cases.

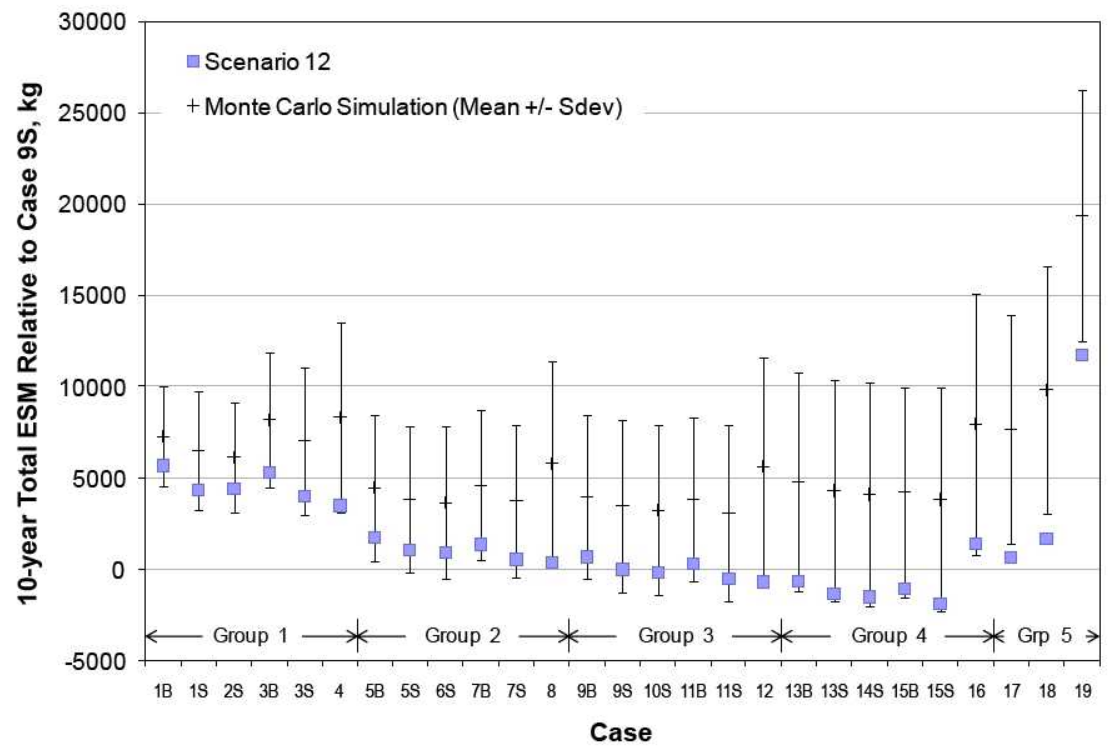

Figure 10. Outpost 10-year total ESM (relative to Case 9S) for baseline cases.

Fig. 10 compares the Outpost 10-year total ESM, which includes both fixed equipment and resupply. The Scenario 12 results show similar trends to the fixed ESM results except for Cases 16, 18 and 19, which were earlier shown to have a negative water balance and thus require resupplied water. In contrast to the fixed ESM results, the 10-year total ESM results from the Monte Carlo simulations show much greater sensitivity (standard deviation) and tend to favor systems with a higher level of closure than the Scenario 12 cases in terms of lowest ESM. The higher mean ESM relative to the Scenario 12 cases is closely related the water and oxygen balance results shown in Figs. 5 and 6. 


\section{ESM Breakdown for Scenario 12 Baseline Cases}

Figs. 11 and 12 show the Scenario 12 breakdown in fixed ESM for the LER and the overall Outpost in terms of mass, volume, power, and cooling contributions. For the LER (Fig. 11), differences in fixed ESM between cases are dominated by power and cooling contributions due to high estimated LER power and cooling equivalencies. The overall Outpost (Fig. 12) shows a mixture of LER and PCM influences, with the LER influences tending to dominate in most cases.

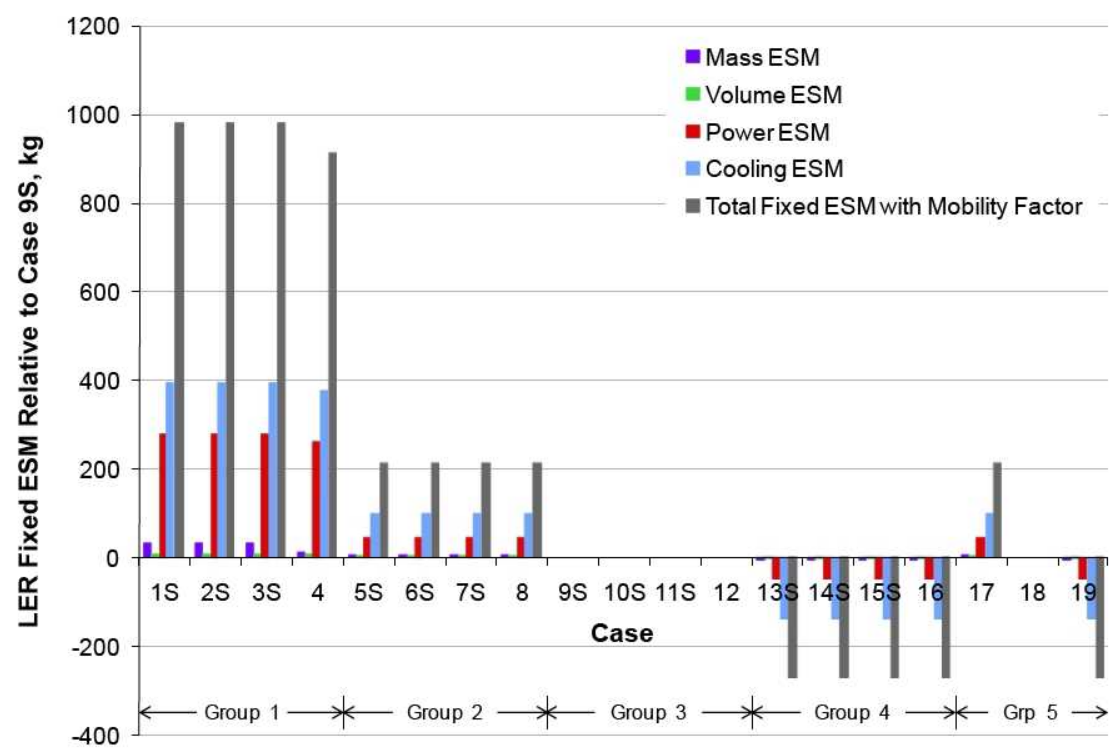

Figure 11. Contributions to the LER fixed ESM (relative to Case 9S) for selected Scenario 12 cases.

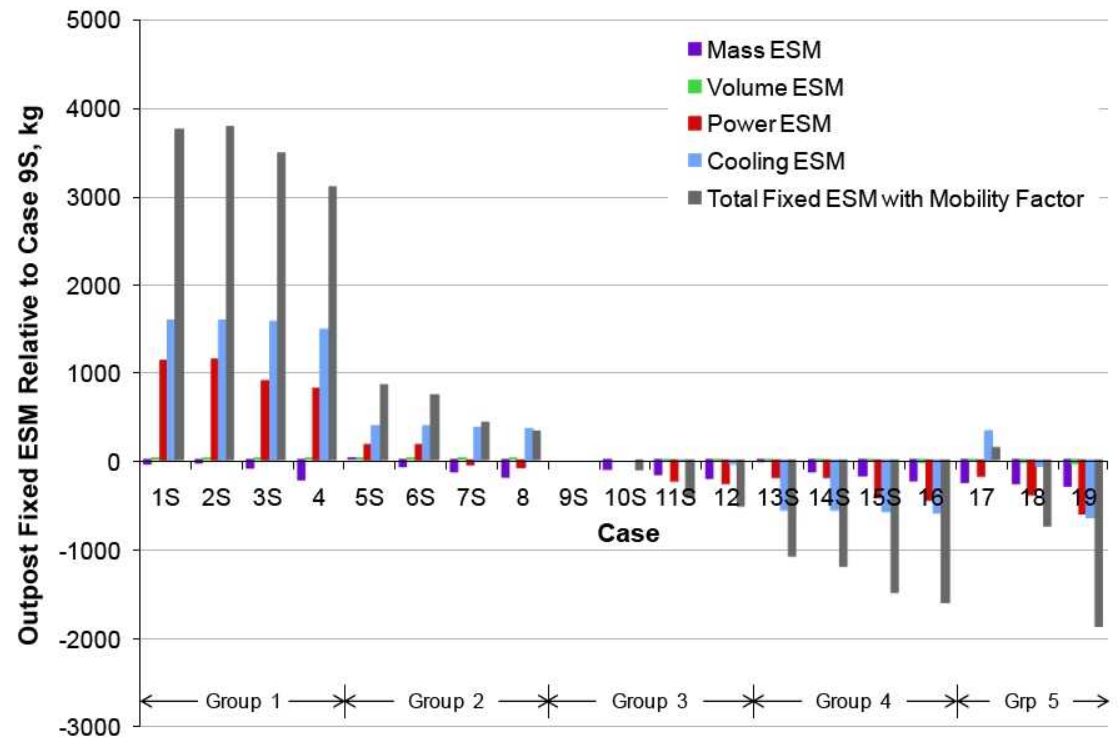

Figure 12. Contributions to the overall Outpost fixed ESM (relative to Case 9S) for selected Scenario 12 cases. 


\section{E. Cost vs. Benefit}

The relation between fixed ESM (based on Scenario 12 assumptions) and the probability of no water or oxygen resupply (from Monte Carlo simulations) is a cost/benefit relation that can be used to compare different architecture cases. Figs. 13 and 14 show such results for the LER and the overall Outpost, respectively. The relations are similar, reflecting the importance of the LER life support equipment on differences in fixed ESM between cases for the Outpost. The better cases in these figures are those that maximize the probability of no water or oxygen resupply for a given ESM. These cases lie along a leading front as illustrated in Fig. 14. An interesting result is that all of the cases along this front include $\mathrm{CO}_{2}$ reduction. They also include cases with water scavenging and electrolysis as well as cases with oxygen scavenging and no electrolysis. It is desirable for technology development to move this front in the direction of reduced ESM and increasing probability of no water or oxygen resupply (down and to the right).

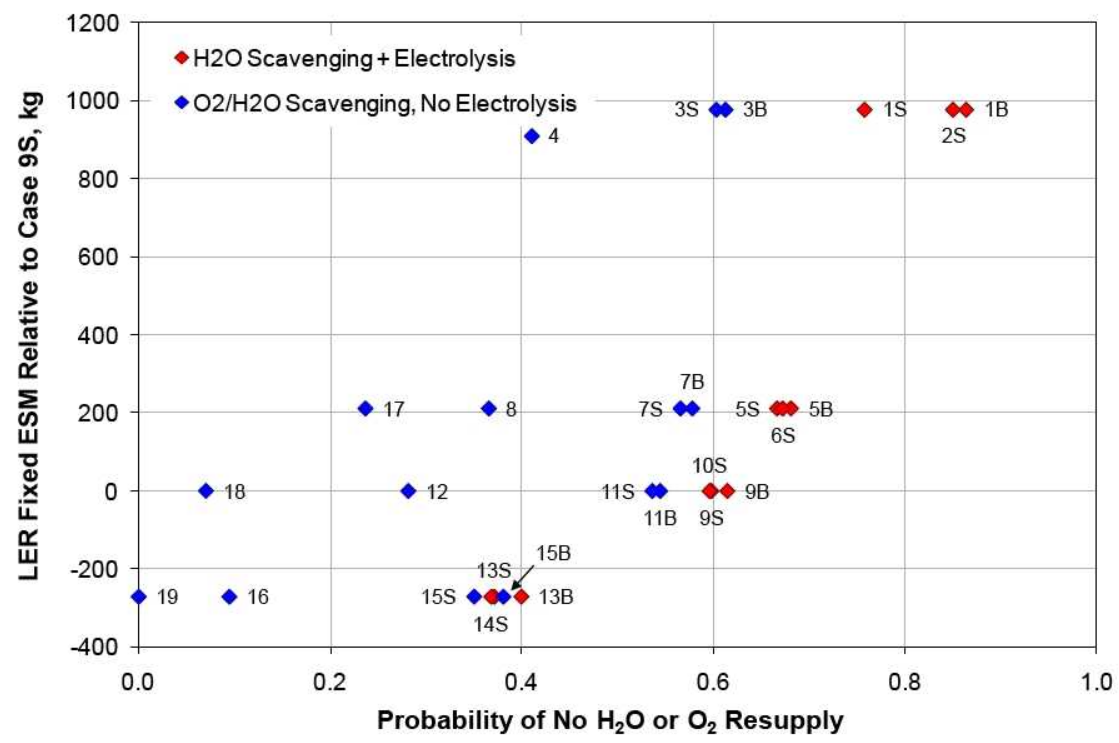

Figure 13. Relation between LER fixed ESM and probability of no water or oxygen resupply. Data point labels are case numbers.

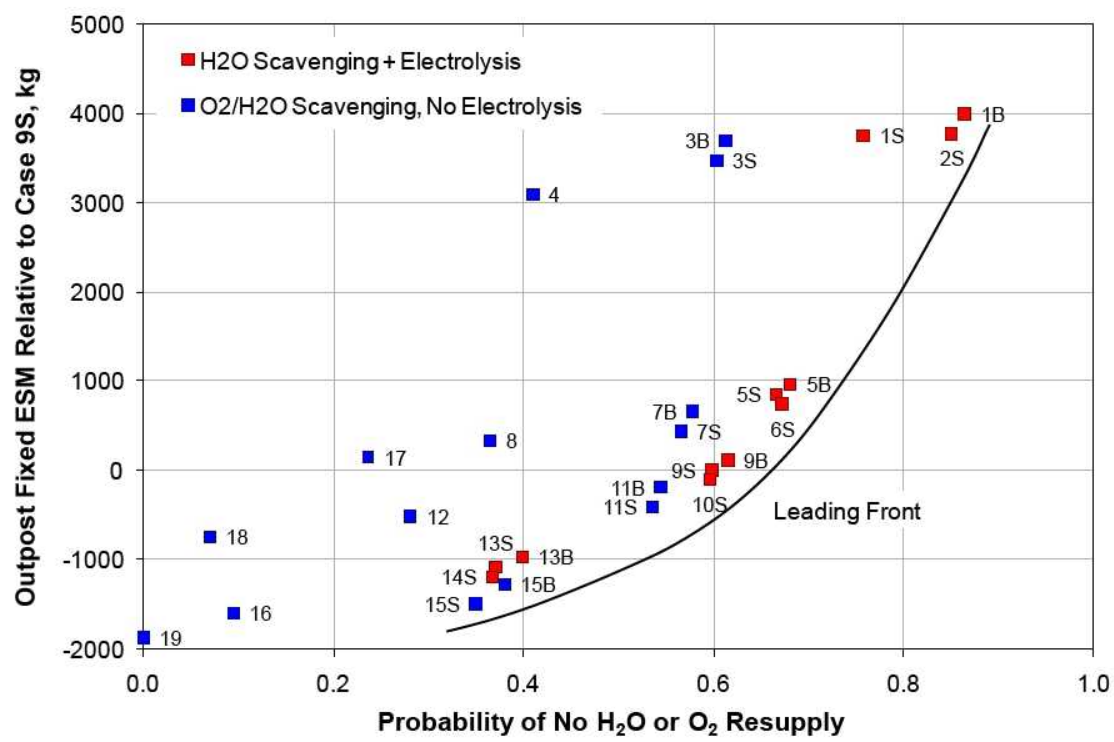

Figure 14. Relation between Outpost fixed ESM and probability of no water or oxygen resupply. Data point labels are case numbers.

14

American Institute of Aeronautics and Astronautics 


\section{Conclusion}

\section{A. Highly Regenerative Life Support Technologies}

If current Scenario 12 assumptions hold (including total EVA hours well below the allowed maximum and a high level of lander propellant scavenging), the results of this study suggest that a range of life support architectures may be possible that result in no water or oxygen resupply. These include apparently simpler architectures with fewer or less complex technologies, but less consumable margin. Alternatively, it may be possible to reduce the criticality of highly regenerative life support technologies, such as complete $\mathrm{CO}_{2}$ reduction and brine/solid-waste water recovery, allowing these technologies to increase the overall robustness and reliability of the system (in terms of measures such as the probability of loss of mission (LOM)) rather than potentially reducing it if they were required to maintain critical consumable supplies. Such reductions in criticality could also lead to technology mass reductions by reducing the required failure tolerance. The magnitude of the increase in system robustness with use of highly regenerative technologies (increasing system closure) is indicated from the Monte Carlo simulations in terms of the probability of no water or oxygen resupply. Alternative architectures and technologies, beyond the limited set considered in this study, may further reduce ESM and increase system robustness.

\section{B. Water versus Oxygen Scavenging}

Results of this study indicate that either water or oxygen scavenging from Lander residual propellants may trade well. In the latter approach, oxygen is first scavenged (up to the needed amount), followed by conversion of remaining oxygen to water (which is also scavenged). Scavenging of excess lander hydrogen is also beneficial for $\mathrm{CO}_{2}$ reduction. Based on current Scenario 12 assumptions, sufficient residual oxygen (from both crew and cargo Landers) is available to meet all life support requirements.

The elimination of water electrolysis with oxygen scavenging provides substantial mass and power savings in the PCM and could improve system reliability. Monte Carlo simulations, however, indicate a lower probability of no water or oxygen resupply compared to similar water scavenging/electrolysis cases. This difference is presumably due to the inability of the oxygen scavenging architectures to convert excess water into oxygen when oxygen scavenging resources are insufficient. A hybrid architecture that uses oxygen scavenging and also has the capability to perform water electrolysis when needed (perhaps as a shared resource with power-system regenerative fuel cells) may prove to be more optimal.

Although In Situ Resource Utilization (ISRU) was not considered in this study, the potential ability of scavenged oxygen to meet life support requirements suggests a simpler single-pass application of ISRU regolith reduction technology in which excess lander hydrogen is used to obtain water from regolith, which is then used for radiation shielding or life support. This more limited application eliminates the need for the ISRU electrolysis and gas storage equipment. Even if scavenged hydrogen is used by life support for $\mathrm{CO}_{2}$ reduction, the potential amount of hydrogen available substantially exceeds that requirement.

This study performed a high-level assessment of alternative scavenging options to assess the potential benefits. More detailed studies are needed to consider handling and storage issues and costs associated with each option. These include losses during transfer and storage, type(s) of storage, and interfaces with the Outpost, LER, and EVA system.

\section{Rover Life Support}

The rover (LER) life support system was found to have a strong influence on differences in overall Outpost ESM between cases. This influence is derived largely from high power and cooling costs on the LER, as well as the number of LER delivered to the Outpost.

Trades on the LER (excursion) $\mathrm{CO}_{2}$ removal system involved compromises between venting valuable resources $\left(\mathrm{H}_{2} \mathrm{O}\right.$ and $\left.\mathrm{CO}_{2}\right)$ and high ESM power and cooling penalties. Based on current Scenario 12 assumptions, the venting RCA system with no water recuperation provided the lowest Outpost 10-year total ESM, while the RCA system with $75 \%$ water recuperation provided the lowest mean ESM from Monte Carlo simulations. Efforts to reduce the cost of water recuperation and $\mathrm{CO}_{2}$ recovery on the LER are clearly suggested from this study.

\section{Extension to Alternative Exploration Missions}

A direct extension of the results and conclusions of this study to alternative microgravity and Lunar/Mars exploration missions is not possible without accounting for potentially large differences in mission parameters and infrastructure costs. The probabilistic approach adopted in this study, however, may be useful in defining life support architectures and technologies that provide low cost/benefit ratios over multiple mission scenarios. For such analyses, the distributed variables could include mission parameters and infrastructure costs. 


\section{Acknowledgments}

The authors wish to thank Dr. Dan Barta, ELS Manager, and Mike Ewert, Deputy ELS Manager, for their support of this work.

\section{References}

${ }^{1}$ Kennedy, K. J., Toups, L. D., and Rudisill, M., "Constellation Architecture Team-Lunar Scenario 12.0 Habitation Overview,” JSC-CN-19362, 2010, NASA Technical Reports Server [online repository], URL: http://ntrs.nasa.gov/search.jsp [cited 22 March 2010].

${ }^{2}$ Bagdigian, R. M., "Challenges with Deploying and Integrating Environmental Control and Life Support Functions in a Lunar Architecture with High Degrees of Mobility," SAE Paper No. 2009-01-2481, 39th International Conference on Environmental Systems, July 2009.

${ }^{3}$ Linne, D. L., D. W. Plachta, D. J. Chato, P. L. Loyselle, S. G. Sutherlin, W. U. Notardonato, J. E. Fittje, K. I. Poast, A. Kashani, L. S. Hornsby and K. P. Prokopius, "Feasibility of Scavenging Propellants from Lander Descent Stage to Supply Fuel Cells and Life Support," AIAA-2009-6511, AIAA SPACE 2009 Conference and Exposition, September 2009.

${ }^{4}$ Polsgrove, T., R. Button, and D. Linne, "Altair Lunar Lander Consumables Management," AIAA 2009-6589, AIAA SPACE 2009 Conference and Exposition, September 2009.

${ }^{5}$ Fisher, J. W., J. A. Hogan, L. Delzeit, K. Wignarajah, R. Alba, G. Pace, and T. G. Fox, "Water Recovery from Wastes in Space Habitats - a Comparative Evaluation of SBIR Prototypes," SAE Paper No. 2009-01-2342, 39th International Conference on Environmental Systems, July 2009. 